\title{
HUBUNGAN ANTARA KEBERADAAN GEN MAJOR HISTOCOMPATIBILITY COMPLEX CLASS II (MHC-II), KETAHANAN TERHADAP PENYAKIT, DAN PERTUMBUHAN PADA POPULASI IKAN MAS STRAIN RAJADANU
}

\author{
Didik Ariyanto"\#, Erma Primanita Hayuningtyas" ${ }^{\circ 9}$, dan Khairul Syahputra") \\ ") Balai Penelitian Pemuliaan Ikan \\ Malai Penelitian dan Pengembangan Budidaya Ikan Hias
}

(Naskah diterima: 2 April 2014; Revisi final: 6 November 2015; Disetujui publikasi: 9 November 2015)

\begin{abstract}
ABSTRAK
Pengembangan budidaya ikan mas di Indonesia mengalami kendala serius sejak timbulnya penyakit koi herpes virus (KHV) pada tahun 2002. Salah satu pendekatan yang dipakai dalam rangka mengantisipasi penyakit tersebut adalah perbaikan mutu genetik untuk mendapatkan varietas unggul ikan mas tahan KHV melalui seleksi berbantuan marka molekuler (MAS; Marker Assisted selection). Keberadaan gen Major Histocompatibility Complex Class II (MHC-II) diduga berkaitan erat dengan peningkatan daya tahan tubuh ikan mas terhadap penyakit. Di sisi lain, populasi ikan dengan daya tahan terhadap penyakit yang tinggi diduga mempunyai laju pertumbuhan lebih lambat. Penelitian ini bertujuan mengetahui empat hal, yaitu (1) transmisi gen MHC-II dari induk ke anakannya, (2) hubungan antara keberadaan gen MHC-II dengan daya tahan terhadap penyakit, (3) hubungan antara daya tahan terhadap penyakit dengan pertumbuhan, serta (4) pengaruh keberadaan gen MHC-II pada ikan mas terhadap performa benih di lingkungan budidaya. Benih uji diperoleh dari pemijahan induk jantan dan betina ikan mas strain Rajadanu positif MHC-II, serta induk jantan dan betina negatif MHC-II. Analisis gen MHC-II dilakukan menggunakan mesin PCR, analisis daya tahan terhadap penyakit melalui uji tantang secara kohabitasi, dan analisis hubungan daya tahan dengan pertumbuhan dilakukan di kolam air deras di daerah endemik KHV, yaitu di Subang, Jawa Barat selama tiga bulan. Hasil penelitian menunjukkan bahwa populasi ikan mas hasil pemijahan induk jantan dan betina positif MHC-II mempunyai persentase $M H C-I I$ sebesar $90 \%$, lebih banyak dibanding populasi hasil pemijahan induk jantan dan betina negatif $M H C-I I$ sebesar $40 \%$. Berdasarkan uji tantang, populasi positif MHC-II mempunyai daya tahan terhadap infeksi KHV 8,95\% lebih tinggi dibanding populasi negatif MHC-II. Hasil pengujian secara lapang di daerah endemik KHV juga menunjukkan pola hasil yang sama, yaitu populasi positif MHC-II mempunyai sintasan 41,61\% lebih baik dibanding populasi negatif MHC-II. Analisis hubungan antara keberadaan gen $M H C-I I$ sebagai indikasi ketahanan terhadap penyakit khususnya KHV dengan pertumbuhan di kolam air tenang maupun kolam air deras menunjukkan bahwa populasi ikan mas Rajadanu dengan persentase $M H C$-II lebih tinggi mempunyai sintasan lebih tinggi tetapi mempunyai laju pertumbuhan lebih lambat.
\end{abstract}

KATA KUNCI: ikan mas, gen MHC, ketahanan terhadap KHV, pertumbuhan

ABSTRACT: The relationship between MHC gene presented in Rajadanu strain of common carp with Its resistance to disease and growth. By: Didik Ariyanto, Erma Primanita Hayuningtyas, and Khairul Syahputra

Development of common carp culture in Indonesia has a serious constrain since specific disease koi herpes virus (KHV) was outbreak in 2002. Marker assisted selection (MAS) was developed in genetic improvement program to get the resistance line of common carp to KHV. MHC gene was proposed as the molekuler marker for resistance fish to disease. In the other hand, the resistance fish which used in aquaculture were suspected had a low growth. This study was conducted to know: 1) the transmission of MHC gen from the parent to its off-spring of Rajadanu common carp strain; 2) the relationship between MHC gene presented in Rajadanu common carp strain with its resistance to spesific disease of KHV; 3) the relationship between resistance to KHV with the growth of Rajadanu common carp strain, and 4) the

\# Korespondensi: Balai Penelitian Pemuliaan Ikan. Jl. Raya 2

Pantura Sukamandi, Patokbeusi, Subang 41263, Jawa Barat,

Indonesia. Tel.: + (0260) 520662

E-mail: didik_ski@yahoo.com 
affected of MHC gene presented in Rajadanu common carp strain to its performance in aquaculture. The fish used in this experiment were obtained from mating of positive MHC male and female brood-stock and also negative MHC male and female brood-stock. MHC gene analyzed with polymerase chain reaction (PCR) techniques. The resistance to KHV of the fish was analyzed from the chalenge test data. Both of the relationship between MHC gene with the growth and the effect of MHC gene to the performance of fish analysis were conducted in running water ponds in Subang distric, as the endemic areas of KHV. The results showed that $90 \%$ of the off-spring from positive MHC male and female broodstock were positive MHC but only 45\% of the off-spring from negative MHC male and female brood-stock were positive MHC. Based on the chalenge test to KHV, the positive MHC population had higher survival rate (93.33\%) than the negative MHC population (85.66\%). The similar result was obtained from the running water ponds culture in endemic of KHV areas, which had survival rate $24.13 \%$ for the positive MHC population and $17.04 \%$ for negative MHC population. Relationship analysis between MHC gene present with growth character showed that Rajadanu common carp strain which positive MHC and higher resistance to KHV population had lower growth than the negative MHC and lower resistance to KHV population.

KEYWORDS: common carp, MHC gene, resistance to KHV, growth

\section{PENDAHULUAN}

Budidaya ikan mas (Cyprinus carpio) di Indonesia telah di mulai sejak akhir abad ke-19. Selama kurun waktu tersebut sampai sekarang budidaya ikan mas terus berlangsung bahkan semakin berkembang. Ikan mas merupakan komoditas yang cukup banyak diproduksi oleh pembudidaya pada luasan hampir di seluruh wilayah Indonesia dan telah memberikan kontribusi ekonomi cukup besar. Hal ini tercermin dari angka produksi ikan mas yang menduduki urutan pertama dari produksi ikan hasil budidaya air tawar pada skala nasional selama kurun waktu 1992-1997. Pada tahun 1996 produksi ikan mas menduduki peringkat pertama dari total produksi nasional ikan hasil budidaya dengan kontribusi sebesar $54,3 \%$ dari jumlah produksi nasional sebesar 328.475 ton atau setara dengan 178.362 ton (Anonim, 1999). Namun demikian, timbulnya wabah penyakit yang disebabkan oleh virus (Koi Herves Virus, KHV) pada sekitar tahun 2002 membuat usaha budidaya ikan mas mengalami penurunan yang sangat drastis.

Dalam rangka mengantisipasi serangan wabah KHV, serta meningkatkan produksi pada kegiatan budidaya ikan mas, telah dilakukan penyusunan program selective breeding di Balai Penelitian Pemuliaan Ikan, Sukamandi sejak tahun 2010. Tujuan akhir program tersebut adalah mendapatkan varietas unggul ikan mas tahan KHV. Koleksi lima populasi ikan mas yang dominan di sentra-sentra budidaya di Jawa Barat, yakni ikan mas strain Majalaya (Bandung), Rajadanu dan Sutisna (Kuningan), Wildan (Cianjur), dan Sinyonya (Pandeglang) telah dilakukan sebagai langkah awal (Ariyanto et al., 2010a). Hasil evaluasi awal terhadap daya tahan kelima strain ikan mas tersebut terhadap KHV menunjukkan bahwa strain Rajadanu mempunyai daya tahan terhadap KHV relatif lebih baik dibanding strain lainnya (Ariyanto et al., 2010b). Berdasarkan hasil evaluasi tersebut, selanjutnya dibentuk populasi dasar (G-0) ikan mas sebagai bahan dasar pembentukan ikan mas tahan KHV. Populasi dasar (G-0) ini terdiri atas individu-individu hasil seleksi berdasarkan marka molekuler Major Histocompatibility Complex (MHC) sebagai gen penyandi daya tahan terhadap penyakit (Rakus et al., 2008) pada 20 famili ikan mas Rajadanu yang bersifat full-sib (Ariyanto et al., 2010c).

Selain karakter daya tahan terhadap penyakit yang selanjutnya berdampak terhadap tingkat kelangsungan hidup (sintasan), salah satu faktor lain yang terkait erat dengan produksi ikan budidaya adalah pertumbuhan. Kedua faktor tersebut (sintasan dan pertumbuhan) diduga mempunyai korelasi yang kuat terhadap daya hasil (produksi) suatu populasi ikan budidaya. Penelitian ini bertujuan mengetahui transmisi gen MHC dari tetua ikan mas ke anakannya, serta hubungan antara keberadaan gen MHC pada ikan mas dengan daya tahan terhadap infeksi penyakit koi herpes virus dan pertumbuhan.

\section{BAHAN DAN METODE}

Bahan utama penelitian adalah populasi anakan ikan mas strain Rajadanu hasil pemijahan induk-induk terseleksi pada populasi G-0. Jumlah induk yang dipijahkan sebanyak empat pasang, terdiri atas dua pasang induk positif $\mathrm{MHC}$ dan dua pasang induk negatif MHC. Pemijahan dilakukan menggunakan metode pemijahan buatan mengikuti SOP pemijahan pada protokol pemuliaan ikan mas yang dikeluarkan oleh Pusat Pengembangan Induk Ikan Mas Nasional (Anonim, 2010a). Pemeliharaan larva dan pendederan benih juga dilakukan sesuai dengan SOP pemeliharaan larva dan pendederan ikan mas pada protokol pemuliaan ikan mas yang dikeluarkan oleh Pusat Pengembangan Induk Ikan Mas Nasional (Anonim, 2010b).

Percobaan dibagi menjadi empat tahap, yaitu 1) evaluasi transmisi gen MHC dari tetua ikan mas ke anakan; 2) evaluasi daya tahan benih ikan mas positif MHC terhadap infeksi penyakit KHV melalui uji tantang; 3) evaluasi hubungan antara pertumbuhan dengan keberadaan gen MHC dan 4) evaluasi keragaan benih ikan mas di lingkungan budidaya. 


\section{Transmisi Gen MHC dari Tetua ke Anakan Ikan Mas}

Tahap pertama ini dilakukan untuk mengetahui persentase anakan ikan mas yang membawa gen MHC sebagai penyandi daya tahan terhadap penyakit. Ikan uji adalah benih ikan mas hasil pemijahan induk jantan dan betina positif MHC, serta induk jantan dan betina negatif MHC, berumur tiga bulan dengan bobot 10-12 g/ekor. Jumlah sampel sebanyak 40 ekor setiap populasi. Analisis gen MHC dilakukan melalui melalui tiga tahapan, yaitu ekstraksi DNA, amplifikasi DNA dalam mesin PCR, dan elektroforesis DNA dalam media gel.

\section{Ekstraksi DNA}

Ekstraksi DNA dilakukan menggunakan metode ekstraksi DNeasy Blood \& Tissue Kits (Qiagen). DNA sampel diekstrak dari organ sirip yang sudah dihancurkan sebanyak 5-10 mg. Secara umum, metodologi yang dilakukan mengikuti prosedur dari Qiagen.

\section{Amplifikasi DNA}

Amplifikasi DNA sampel pada mesin PCR dilakukan dengan kit Maxima Hot Start Green PCR master Mix (2X) (Fermentas, Thermo Scientific). Komposisi pereaksi PCR diantaranya adalah: $1 \mu \mathrm{L}$ primer forward (CTAATGGATACTACTGG), $1 \mu \mathrm{L}$ primer reverse (ATCGCTGACTGTCTGTT) (Sucipto, 2011), $1 \mu \mathrm{L}$ DNA $(450 \mu \mathrm{g} / \mathrm{mL})$ dan nuclease free water sampai total volume $25 \mu \mathrm{L}$. PCR dilakukan menggunakan thermocycler gradient (Esco), dengan program terdiri atas denaturasi awal pada suhu $95^{\circ} \mathrm{C}$ selama tiga menit, 30 siklus selanjutnya terdiri atas denaturasi pada suhu $95^{\circ} \mathrm{C}$ selama 30 detik, annealing pada suhu $49,1^{\circ} \mathrm{C}$ selama 30 detik dan extension pada suhu $72^{\circ} \mathrm{C}$ selama satu menit. Program diakhiri dengan final extension pada suhu $72^{\circ} \mathrm{C}$ selama tujuh menit dan pengkondisian akhir pada suhu $4^{\circ} \mathrm{C}$. Hasil PCR dapat langsung dielektroforesis atau disimpan dalam freezer. Sebagai kontrol internal digunakan gen ß-aktin ikan mas dengan panjang fragmen $300 \mathrm{bp}$, primer yang digunakan adalah F: 5'-CCC TGG CCC CCA GCA CAA TG-3' dan R: 5'-TCT GCG CAG TTG AGT CGG CG-3'.

\section{Elektroforesis}

Elektroforesis dilakukan pada gel agarosa dengan konsentrasi sebesar 1,5\%. Bahan utama berupa $5 \mu \mathrm{L}$ produk PCR yang sudah terdapat loding dye di dalamnya. Deretan produk PCR yang sudah di-loading di-running bersamaan dengan leader marker ukuran 100 bp sebanyak $4 \mu \mathrm{L}$. Elektroforesis dilakukan dengan menggunakan arus listrik $80 \mathrm{~V}$ selama 35 menit. Individu yang membawa gen MHC akan terlihat pada pita (band) hasil elektroforesis pada ukuran $300 \mathrm{bp}$. Berdasarkan hasil tersebut, jumlah individu positif MHC pada masing-masing populasi dapat dihitung.

\section{Evaluasi Daya Tahan Benih Ikan Mas Terhadap Infeksi KHV}

Evaluasi daya tahan benih ikan mas terhadap KHV dilakukan untuk mengetahui pengaruh keberadaan gen MHC pada induk yang diturunkan kepada anakannya terhadap daya tahan benih dalam menghadapi infeksi KHV. Ikan uji adalah benih ikan mas hasil pemijahan induk jantan dan betina positif MHC, serta induk jantan dan betina negatif MHC, berumur tiga bulan dengan bobot 10-12 g/ekor. Evaluasi daya tahan infeksi KHV dilakukan melalui uji tantang secara laboratoris menggunakan metode kohabitasi, mengikuti prosedur dalam protokol kegiatan pemuliaan ikan mas (Anonim, 2010b). Wadah uji tantang berupa enam unit akuarium berukuran $60 \mathrm{~cm}$ x $40 \mathrm{~cm}$ x $40 \mathrm{~cm}$ yang diisi air $30 \mathrm{~L} /$ akuarium. Setiap akuarium diisi 30 ekor ikan uji ditambah ikan sumber KHV sebanyak 10\% dari jumlah ikan uji. Ikan uji yang digunakan harus memiliki status kesehatan bebas dari KHV, serta bebas dari parasit dan bakteri. Jika positif KHV ikan tidak bisa digunakan, sementara jika terinfeksi bakteri dan parasit harus disembuhkan terlebih dahulu.

Sebelum pelaksanaan uji tantang, yang dilakukan adalah menyiapkan filtrate homogenete KHV. Filtrat homogenate KHV diperoleh dari insang ikan mas yang terinfeksi KHV yang dihancurkan, kemudian disentrifuge selama 15 menit pada kecepatan $5.000 \mathrm{rpm}$ lalu disaring menggunakan syrige filter $0,45 \mathrm{~mm}$. Langkah kedua adalah menyediakan ikan sumber KHV dengan cara menginjeksikan filtrate homogenate KHV dengan dosis $0,1 \mathrm{~mL} / \mathrm{ekor}$ ke tubuh benih ikan mas yang sehat. Setelah diinjeksi dengan filtrate homogenate $\mathrm{KHV}$, calon ikan sumber $\mathrm{KHV}$ dipelihara pada akuarium dengan air bersuhu rendah berkisar $21^{\circ} \mathrm{C}$ $23^{\circ} \mathrm{C}$. Suhu air tersebut sesuai dengan media perkembangan penyakit KHV. Ikan yang memiliki gejala klinis terinfeksi KHV diverifikasi secara molekuler untuk memastikan terinfeksi KHV. Ikan yang positif terinfeksi KHV dipisahkan dan diberi penandaan berupa pemotongan sirip ekor untuk membedakan dengan ikan uji pada waktu uji tantang dilaksanakan.

Selain menyediakan ikan sumber KHV, benih uji disiapkan sebelum pelaksanaan uji tantang melalui aklimatisasi pada suhu $21^{\circ} \mathrm{C}-23^{\circ} \mathrm{C}$ selama $1-2$ hari. Suhu air pada akuarium uji tantang juga dikondisikan pada suhu yang permisif bagi berkembangnya virus $\mathrm{KHV}$, berkisar antara $21^{\circ} \mathrm{C}-23^{\circ} \mathrm{C}$. Setelah proses aklimatisasi, ikan uji dan ikan sumber KHV secara bersamaan dimasukkan ke dalam akuarium uji. Uji tantang dilakukan selama 21 hari pemeliharaan. Selama masa uji tantang, ikan diberi pakan secukupnya untuk dapat bertahan hidup. Ikan uji yang mengalami kematian dengan gejala klinis terserang 
KHV diverifikasi secara molekuler untuk memastikan terinfeksi KHV. Penyiponan untuk membuang sisa pakan dan kotoran, serta penggantian air selama masa uji tantang dilakukan setiap hari untuk menjaga kualitas air media pemeliharaan tetap dalam kisaran yang baik bagi ikan. Parameter utama yang diamati adalah tingkat sintasan kedua populasi benih pada akhir kegiatan.

\section{Evaluasi Hubungan Antara Pertumbuhan dengan Keberadaan Gen MHC}

Evaluasi hubungan pertumbuhan dengan keberadaan gen MHC dilakukan di kolam tanah ukuran $400 \mathrm{~m}^{2}$ dengan kepadatan 10 ekor $/ \mathrm{m}^{2}$. Benih uji merupakan benih hasil pemijahan induk jantan dan betina positif MHC, berumur tiga bulan dengan bobot 10-12 g/ekor. Selama empat bulan pemeliharaan, ikan diberi pakan buatan berbentuk pelet dengan kandungan protein kasar 28\%. Pemberian pakan sebanyak 3\% dari biomassa per hari dilakukan dua kali, yaitu pada waktu pagi (09.00) dan sore (16.00). Pada akhir bulan ke-4 dilakukan panen terhadap ikan yang dipelihara, selanjutnya dilakukan pemilihan individu ikan untuk dikelompokkan menjadi dua. Kelompok pertama adalah 20\% ikan berukuran terbesar dengan bobot individu 544,43 \pm 39,24 g/ ekor dan kelompok kedua adalah 20\% ikan dengan ukuran terkecil dengan bobot individu 119,36 \pm 33,02 g/ekor. Kelompok ikan ukuran besar merepresentasikan ikan-ikan dengan pertumbuhan cepat sedangkan kelompok ukuran kecil merepresentasikan ikan-ikan dengan pertumbuhan lambat. Sebanyak 28 ekor individu dari masingmasing kelompok diambil secara acak yang terbagi dalam empat sub kelompok sebagai ulangan untuk analisis keberadaan gen MHC. Analisis gen MHC menggunakan metode yang sama dengan analisis MHC pada tahap evaluasi transmisi gen. Pada akhir kegiatan, dihitung persentase individu positif $\mathrm{MHC}$ dari masing-masing ulangan, baik pada kelompok ikan berukuran besar maupun kecil.

\section{Evaluasi Keragaan Benih Ikan Mas di Lingkungan Budidaya}

Evaluasi keragaan benih ikan mas di lingkungan budidaya dimaksudkan untuk mengevaluasi pertumbuhan, serta daya tahan benih terhadap penyakit. Evaluasi keragaan benih dilakukan di kolam air deras di daerah Subang yang endemik wabah penyakit KHV. Benih uji adalah benih ikan mas hasil pemijahan induk jantan dan betina positif MHC. Sebagai pembanding digunakan benih ikan mas hasil pemijahan induk jantan dan betina negatif $\mathrm{MHC}$. Pemeliharaan ikan dilakukan menggunakan kantong jaring ukuran 2,5 m x 2,5 m x 1,5 m dengan kepadatan
50 ekor $/ \mathrm{m}^{2}$. Pemeliharaan kedua populasi benih ikan dilakukan dengan tiga kali ulangan. Selama tiga bulan pemeliharaan, benih ikan diberi pakan buatan komersil dengan kandungan protein kasar 28\% sebanyak 7,5\%; $5 \%$; dan $2,5 \%$ per hari berturut-turut dari bulan 1,2 , dan 3. Pemberian pakan diberikan dua kali sehari setiap pagi dan sore. Pada akhir bulan ketiga, dilakukan panen terhadap semua benih. Parameter yang diamati adalah bobot rata-rata individu, sintasan, serta biomassa total panen.

\section{Analisis Data}

Tingkat sintasan hasil uji tantang benih ikan mas dianalisis menggunakan uji t pada taraf $ß=0,05$. Data hubungan antara pertumbuhan dengan persentase individu yang membawa gen $\mathrm{MHC}$ dianalisis dengan analisis korelasi dan regresi, sedangkan nilai transmisi gen MHC dari induk ke anakannya dan keragaan benih ikan mas pada media budidaya dianalisis secara deskriptif. Tabulasi dan analisis data dilakukan dengan menggunakan program komputer Excell ${ }^{\circledR}$ for Windows $^{\circledR} 2007$.

\section{HASIL DAN BAHASAN}

\section{Transmisi Gen MHC pada Induk ke Anakannya}

Contoh hasil elektroforesis pada identifikasi keberadaan gen MHC pada individu sampel ikan mas disajikan pada Gambar 1 dan hasil analisis persentase individu benih ikan mas yang membawa gen $\mathrm{MHC}$ disajikan pada Gambar 2. Pada Gambar 2 terlihat bahwa persilangan antara induk jantan dan betina positif MHC menghasilkan persentase benih yang membawa gen MHC lebih tinggi dibandingkan dengan persilangan antara induk jantan dan betina negatif $\mathrm{MHC}$.

Tingginya persentase benih yang membawa gen MHC pada persilangan antara induk jantan dan betina positif MHC sebesar 90\% diduga karena masingmasing induk bersifat homozigot positif $\mathrm{MHC}$ sehingga sebagian besar segregasi gamet pada turunannya membawa gen MHC. Pada populasi benih hasil persilangan induk jantan dan betina negatif MHC, adanya benih yang membawa gen MHC diduga diperoleh dari salah satu atau kedua tetuanya yang diduga bersifat heterozigot positif MHC. Hal ini mengindikasikan bahwa induk-induk yang terdeteksi negatif MHC belum tentu tidak mempunyai gen penyandi ketahanan terhadap penyakit tersebut. Gen MHC yang berada pada indukinduk tersebut tidak terdeteksi pada pengujian secara laboratorium diduga karena bersifat heterozigot. Hal ini mengakibatkan jumlah benih positif MHC pada hasil persilangan tersebut tidak terlalu banyak, yaitu $45 \%$. 


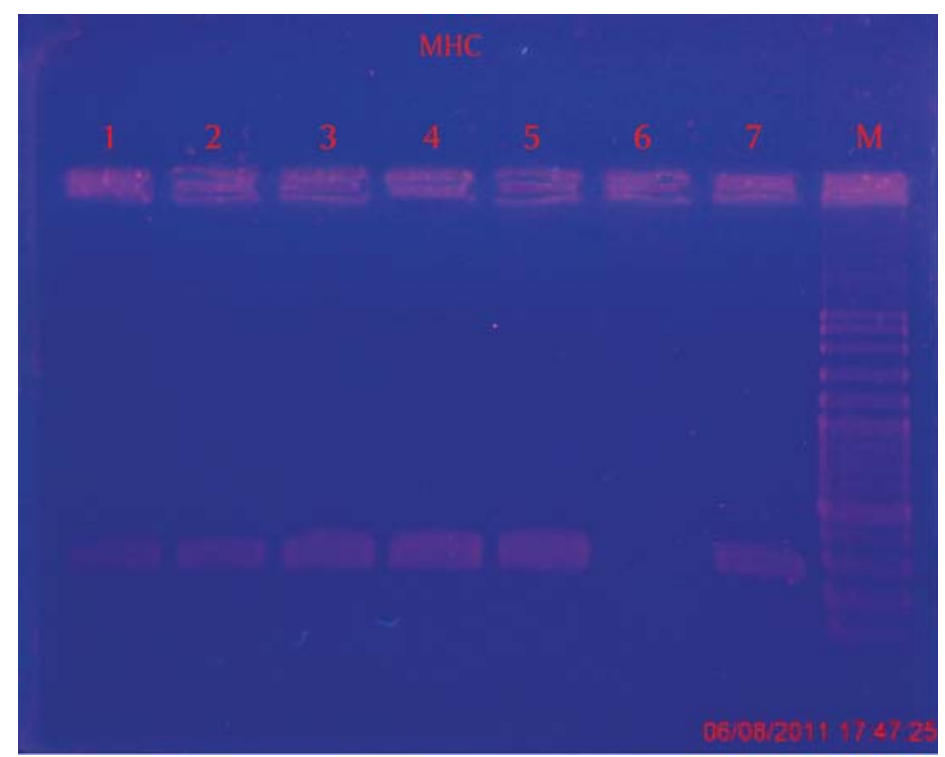

Gambar 1. Hasil elektroforesis identifikasi keberadaan gen MHC pada sampel benih ikan mas Rajadanu; Nomor 1-5 dan 7 merupakan individu positif MHC (300 bp) sedangkan nomor 6 merupakan individu negatif MHC. M: marker

Figure 1. Electrophoresis result for MHC identification in Rajadanu common carp strain; sample 1-5 and 7 represented the positive MHC and sample 6 represented negative MHC. M: marker

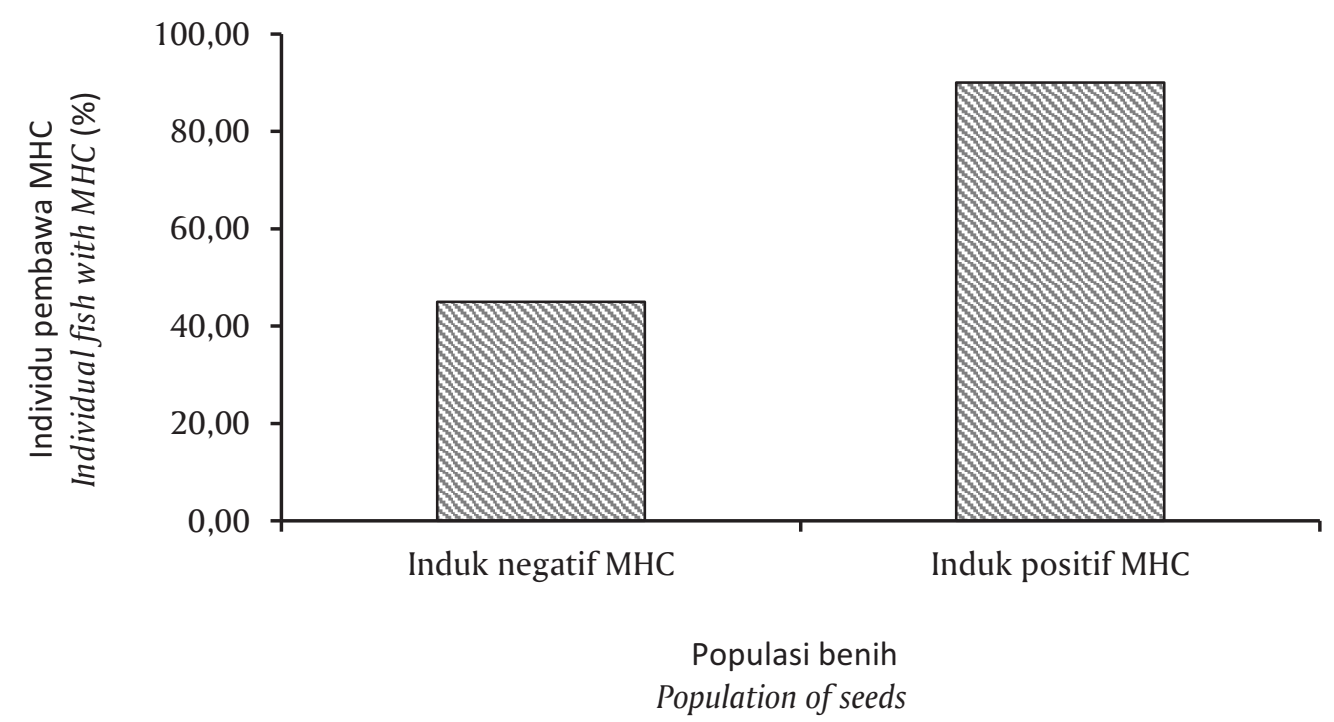

Gambar 2. Persentase benih ikan mas yang membawa gen MHC pada masingmasing persilangan ikan mas

Figure 2. The percentage of individual fish with MHC gene in each crossing of Rajadanu common carp

\section{Evaluasi Daya Tahan Benih terhadap KHV}

Hasil analisis uji tantang secara kohabitasi di laboratorium disajikan pada Gambar 3. Hasil analisis menunjukkan bahwa populasi benih hasil persilangan antara induk jantan dan betina positif MHC mempunyai nilai sintasan relatif lebih tinggi sebesar 93,33 $\pm 6,67 \%$ dibanding populasi benih hasil persilangan induk jantan dan betina negatif MHC sebesar 85,56 $\pm 25,02 \%$. Meskipun tidak berbeda secara nyata, namun hal ini 


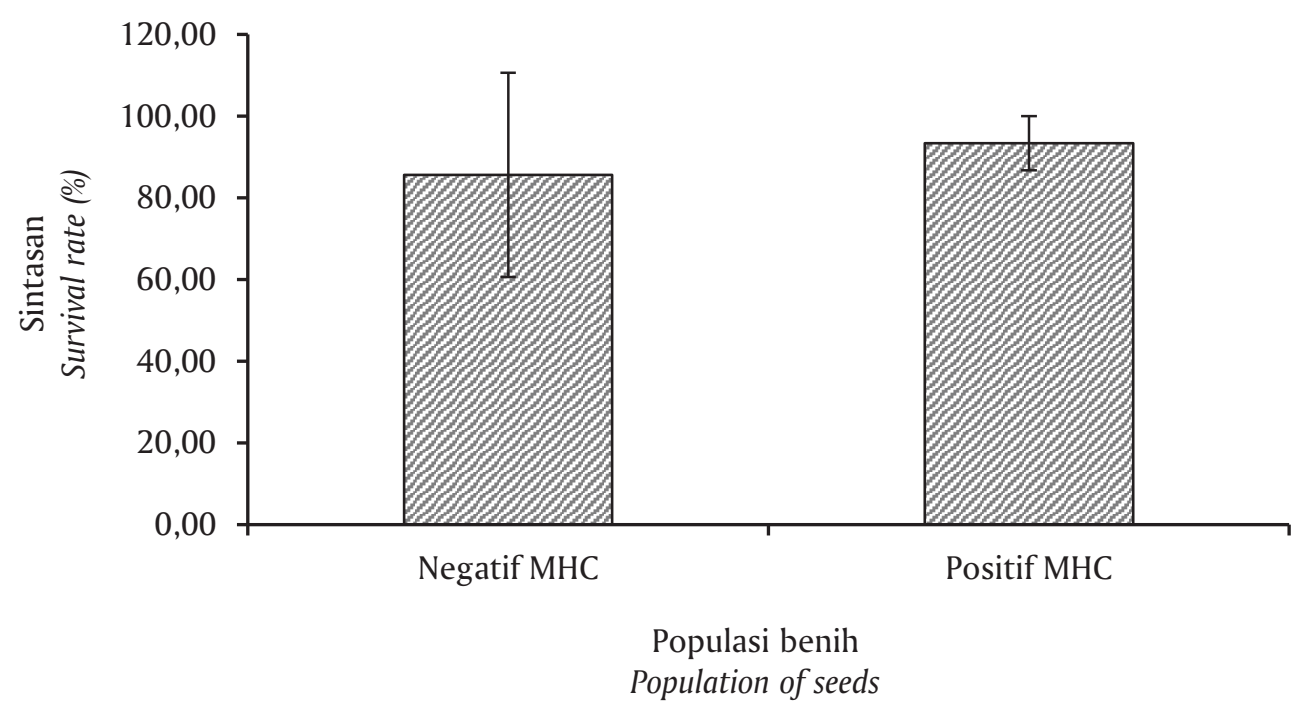

Gambar 3. Sintasan masing-masing populasi benih ikan mas pada uji tantang dengan KHV

Figure 3. Survival rate of each population of Rajadanu common carp in chalenge tes with $\mathrm{KHV}$

mengindikasikan bahwa populasi dengan persentase MHC lebih tinggi mempunyai daya tahan terhadap infeksi KHV lebih baik, ditandai dengan lebih tingginya nilai sintasan populasi tersebut pada uji tantang.

Gen MHC merupakan kandidat gen penanda (marker gene) pada studi ketahanan terhadap penyakit. Gen MHC mempunyai sejumlah gen polimorfik yang sudah diketahui berhubungan dengan imunitas. Masingmasing molekul gen MHC mempunyai kemampuan untuk bergabung dan menghadirkan peptida dari kelompok molekul yang berbeda secara sempurna maupun tidak. Hal ini menyebabkan respons imun pada organisme yang menerima turunan (derivate) peptida dari suatu penyakit tertentu, dapat diperoleh dari molekul MHC spesifik atau kemungkinan diperoleh dari molekul MHC yang lain. Jika respons imun diperoleh dari MHC yang tidak spesifik, hal ini dapat menyebabkan tingkat kerentanan yang tinggi dari organisme tersebut terhadap suatu penyakit tertentu, atau sebaliknya, jika respons imun diperoleh dari molekul MHC spesifik, akan meningkatkan resistansi organisme terhadap penyakit tersebut (Klein et al., 2007). Hubungan antara resistansi pada penyakit dengan gen MHC yang sudah dipelajari adalah pada infeksi malaria pada manusia (Hill et al., 1991) dan juga penyakit virus pada ayam (Briles et al., 1977; Kaufman \& Wallny, 1996). Namun demikian, pada ikan teleostei, secara genomik gen MHC mempunyai susunan yang berbeda. Di sini, gen MHC kelas I dan II berada pada kromosom berbeda dan bersegregasi secara terpisah. Hal ini memungkinkan adanya asosiasi antara gen MHC kelas I atau MHC kelas II saja terhadap resistensi terhadap penyakit. Secara umum, dalam sebuah respons imun terhadap penyakit viral, derivat peptida virus yang berasal dari biosintesis cytosolic virus dihadirkan oleh molekul MHC kelas I menjadi cytotoxic pada $\mathrm{CD}^{+}$sel T. Sedangkan molekul MHC kelas II dapat menghadirkan derivat peptida virus dari degradasi pada bagian endosomal/lysosomal, menjadi $\mathrm{CD}^{+}$sel T. Proses-proses tersebut memacu produksi interveron yang mampu beraksi membendung penyebaran virus dan juga menstimulasi produksi antibodi spesifik. Meskipun hanya merupakan fraksi minor, antibodi ini mempunyai aktivitas langsung sebagai antivirus, di mana antibodi akan membantu mengontrol infeksi virus dengan mengaktifkan sistem komplemen, memfasilitasi fagositosis, dan mengaktifkan antibodi-bebas dari sel cytotoxic.

Beberapa hasil studi pada manusia dan tikus menjelaskan bahwa $\mathrm{CD}^{+}{ }^{+}$sel $\mathrm{T}$ merupakan sesuatu hal yang penting dalam mengontrol infeksi herpesvirus (Heller et al., 2006, Wiertz et al., 2007). Studi pada herpesvirus tikus MHV-68 menunjukkan bahwa $\mathrm{CD}^{+}$ sel T mampu mengontrol infeksi in vivo, independensi $\mathrm{CD}^{+}{ }^{+}$sel T dan sel B (Christensen et al., 1999). Hal ini juga menunjukkan bahwa kehadiran glycoprotein virus Epstein Barr (EBV) oleh molekul MHC kelas II mampu membunuh secara langsung virus tersebut yang menginfeksi sel $\mathrm{B}$ menggunakan $\mathrm{CD} 4^{+}$sel $\mathrm{T}$ (Landais et al., 2004, Heller et al., 2006). Dalam 
penelitian ini, diduga persentase individu positif gen MHC yang lebih tinggi pada populasi ikan mas hasil persilangan induk jantan dan betina positif MHC mempunyai peranan yang signifikan terhadap peningkatan imun sistem pada tubuh ikan sehingga menghasilkan sintasan yang lebih baik dibandingkan populasi benih ikan hasil persilangan induk jantan dan betina negatif MHC.

\section{Evaluasi Hubungan Antara Pertumbuhan dengan Keberadaan Gen MHC}

Hasil analisis hubungan antara bobot rata-rata individu dengan persentase individu yang positif $\mathrm{MHC}$ disajikan pada Gambar 4. Secara umum, hasil analisis menunjukkan bahwa populasi dengan bobot lebih tinggi (laju pertumbuhan cepat) mempunyai persentase MHC lebih rendah. Hasil analisis korelasi antara kedua parameter tersebut menunjukkan bahwa karakter bobot berkorelasi negatif $(-0,779)$ dengan persentase MHC dalam populasi dengan nilai $\mathrm{R}^{2}$ sebesar 0,607 .

Bureau et al. (2002) menjelaskan bahwa dalam hukum kekekalan energi disebutkan bahwa jumlah total energi dalam suatu sistem bersifat tetap. Energi dapat ditransfer dari satu bagian ke bagian lainnya ataupun ditransformasi menjadi bentuk energi yang berbeda. Dalam konteks tersebut, total energi dalam sistem tubuh ikan terbagi-bagi untuk beberapa keperluan antara lain untuk sintasan tetap (basal energy), reproduksi, pertahanan terhadap perubahan lingkungan termasuk penyakit, pertumbuhan, dan lainnya. Kebutuhan utama adalah untuk bertahan hidup kemudian reproduksi, pertahanan dan jika masih tersisa untuk pembentukan sel-sel baru yang disimpan dalam bentuk jaringan otot yang juga sebagai cadangan energi. Penimbunan jaringan otot tersebut yang kita kenal dengan pertumbuhan. Maka jika kebutuhan energi untuk pertahanan terhadap perubahan lingkungan maupun penyakit semakin besar, secara otomatis terjadi transaksi energi dari pertumbuhan menjadi energi untuk pertahanan.

Ditambahkan oleh Shoemaker et al. (2001) bahwa berdasarkan penelitian sebelumnya, keberadaan gen MHC pada ikan diduga mempunyai fungsi yang sama dengan gen MHC pada mamalia, yaitu sebagai gen yang bertugas mengeliminasi patogen dalam sel. Kemampuan pertahanan terhadap infeksi penyakit (imunitas) oleh gen MHC akan menstimulasi sel T-helper untuk memproduksi cytokines yang selanjutnya akan menstimulasi sel-sel effector (cytotoxic limphocytes). Cytokines juga berperan dalam pembentukan sel-sel baru terkait rusaknya sel akibat infeksi penyakit. Selain itu, cytokines juga berperan dalam untuk mempertahan diri dari serangan penyakit dengan menstimulasi macrophages untuk meningkatkan kemampuan membunuh jasad patogen sehingga menurunkan kemampuan infeksiusnya. Ditambahkan bahwa cytokines tersebut adalah polipeptida sederhana atau glikoprotein yang beraksi sebagai molekul signal pada sistem imun tubuh. Sistem pertahanan

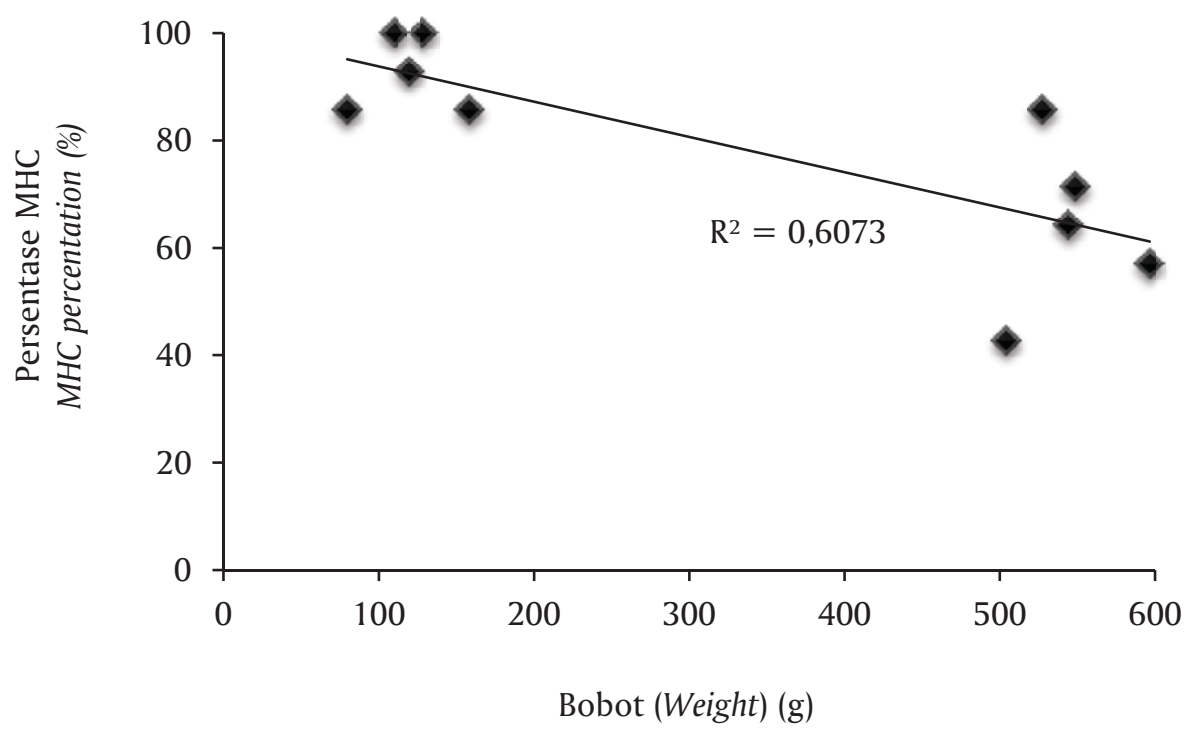

Gambar 4. Hubungan antara kelompok ikan dengan bobot badan berbeda dengan persentase gen MHC pada populasi ikan mas strain Rajadanu

Figure 4. Relationship between the different body weight of fish group and percentage of individual fish with MHC-II in Rajadanu common carp strain 
terhadap penyakit yang melibatkan gen MHC, cytokines, macrophages, dan lainnya ini juga membutuhkan energi yang akhirnya berdampak terhadap jumlah energi yang tersisa untuk ditimbun sebagai jaringan otot sehingga secara fenotipe terlihat bahwa laju pertumbuhannya semakin rendah.

\section{Evaluasi Keragaan Benih Ikan Mas di Lingkungan Budidaya}

Hasil evaluasi keragaan populasi benih ikan mas hasil persilangan induk jantan dan betina yang positif maupun negatif MHC di kolam air deras wilayah endemik KHV disajikan pada Tabel 1.

Keragaan kedua populasi benih ikan mas yang dipelihara di kolam air deras endemik KHV di wilayah Subang, Jawa Barat menunjukkan kecenderungan yang berbeda antara lain pada laju pertumbuhan, tingkat sintasan, bobot rata-rata, dan biomassa total pada waktu panen. Kecenderungan ini mengindikasikan adanya pengaruh keberadaan gen MHC pada suatu populasi terhadap keragaan populasi tersebut. Meskipun bobot rata-rata benih ikan mas positif MHC lebih rendah dibanding populasi benih negatif $\mathrm{MHC}$, tetapi populasi tersebut mempunyai tingkat sintasan lebih tinggi sehingga berdampak terhadap biomassa total pada waktu panen yang lebih baik.

Beberapa hasil penelitian menunjukkan korelasi positif antara karakter pertumbuhan dengan daya tahan terhadap penyakit, misalnya pada ikan rainbow trout (Oncorhynchus mykiss) (Overturf et al., 2010) dan ikan gilthead sea bream (Sparus aurata L.) (Antonelo et al., 2009). Namun demikian, beberapa penelitian lainnya menunjukkan tidak adanya korelasi antara kedua karakter tersebut seperti pada ikan cod Atlantik (Bangera et al., 2011), bahkan menunjukkan korelasi negatif seperti pada ikan mas di Rusia (Kirpichnikov et al., 1993). Hasil penelitian ini menunjukkan bahwa keberadaan marka molekuler MHC berkorelasi positif terhadap daya tahan ikan mas Rajadanu tetapi berdampak terhadap penurunan laju pertumbuhan populasi tersebut. Hasil uji lapangan ini sesuai dengan hasil uji tantang benih di laboratorium yang menunjukkan bahwa populasi positif MHC mempunyai daya tahan terhadap penyakit lebih baik dibanding populasi negatif MHC. Wetten et al. (2007) juga melaporkan hal yang sama pada ikan salmon Atlantik yang menunjukkan bahwa terdapat korelasi positif antara hasil uji skala lapang pada daerah endemik penyakit IPN (infectious pancreatic necrosis) dengan uji tantang di laboratorium.

\section{KESIMPULAN}

Populasi ikan mas hasil pemijahan induk jantan dan betina positif MHC-II mempunyai persentase MHC-II sebesar $90 \%$, lebih banyak dibanding populasi hasil pemijahan induk jantan dan betina negatif $\mathrm{MHC}-\mathrm{II}$ sebesar $40 \%$ dan berdasarkan uji tantang secara laboratoris mempunyai daya tahan terhadap infeksi KHV 8,95\% lebih tinggi dibanding populasi negatif MHC-II. Hasil pengujian secara lapang di daerah endemik KHV menunjukkan bahwa populasi positif MHC-II mempunyai sintasan 41,61\% lebih baik dibanding populasi negatif $M H C-I I$.

Tabel 1. Keragaan populasi benih ikan mas dari induk jantan dan betina positif dan negatif MHC yang dipelihara di kolam air deras endemik KHV selama tiga bulan

Table 1. The performance seed of Rajadanu common carp strain from the broodstock which had positive and negative MHC-II gene reared in endemic KHV disease running water pond for three months

\begin{tabular}{lcc}
\hline \multicolumn{1}{c}{$\begin{array}{l}\text { Parameter } \\
\text { Parameters }\end{array}$} & \multicolumn{2}{c}{ MHC } \\
\cline { 2 - 3 } & Positif (Positive) & Negatif (Negative) \\
\hline $\begin{array}{l}\text { Laju pertumbuhan spesifik (\%/hari) } \\
\text { Specific growht rate (\%/days) }\end{array}$ & $2.90 \pm 0.49$ & $3.05 \pm 0.21$ \\
$\begin{array}{l}\text { Sintasan } \\
\text { Survival rate (\%) }\end{array}$ & $25.33 \pm 9.77$ & $17.89 \pm 11.74$ \\
$\begin{array}{l}\text { Rasio konversi pakan } \\
\text { Feed convertion ratio } \\
\text { Bobot rata-rata } \\
\text { Average weight }(\mathrm{g})\end{array}$ & $3.12 \pm 1.45$ & $3.25 \pm 1.82$ \\
$\begin{array}{l}\text { Biomassa total } \\
\text { Total biomass }(\mathrm{g})\end{array}$ & $89.46 \pm 33.79$ & $105.37 \pm 27.73$ \\
\hline
\end{tabular}


Analisis hubungan antara keberadaan gen MHC-II sebagai indikasi ketahanan terhadap penyakit khususnya KHV dengan pertumbuhan di kolam air deras menunjukkan bahwa populasi ikan mas Rajadanu dengan persentase MHC-II lebih tinggi mempunyai sintasan lebih tinggi tetapi mempunyai laju pertumbuhan lebih lambat.

\section{DAFTAR ACUAN}

Anonim. (1999). Statistik perikanan Indonesia 1996. Direktorat Jenderal Perikanan Budidaya. Jakarta.

Anonim. (2010a). Laporan kegiatan pengembangan ikan mas di BBPBAT, Sukabumi. Naskah disampaikan pada Temu Jejaring Pengembangan Induk Ikan Mas Nasional. Sukabumi, 9-11 November 2010.

Anonim. (2010b). Protokol pemuliaan ikan mas. Pusat Pengembangan Induk Ikan Mas Nasional. Direktorat Jenderal Perikanan Budidaya. Kementerian Kelautan dan Perikanan. $39 \mathrm{hlm}$.

Antonello, J., Massault, C., Franch, R., Haley, C., Pellizzari, C., Patarnello, T., de Koning, D., \& Bargelloni, L. (2009). Estimates of heritability and genetic correlation for body length and resistance to ûsh pasteurellosis in the gilthead sea bream (Sparus aurata L.). Aquaculture, 298, 29-35.

Ariyanto, D., Hayuningtyas, E.P., \& Syahputra, K. (2010a). Koleksi dan karakterisasi populasi ikan mas sebagai bahan pembentuk ikan mas tahan KHV. Seminar Hasil Penelitian LRPTBPAT tahun 2010. Sukamandi, 13-14 Desember 2010.

Ariyanto, D., Hayuningtyas, E.P., \& Syahputra, K. (2010b). Evaluasi daya tahan lima strain ikan mas terhadap KHV. Seminar Hasil Penelitian LRPTBPAT tahun 2010. Sukamandi, 13-14 Desember 2010.

Ariyanto, D., Hayuningtyas, E.P., \& Syahputra, K. (2010c). Pembentukan populasi dasar ikan mas tahan KHV. Seminar Hasil Penelitian LRPTBPAT tahun 2010. Sukamandi, 13-14 Desember 2010.

Bangera, R., Ødegård, J., Præbel, A.K., Mortensen, A., \& Nielsen, H.M. (2011). Genetic correlations between growth rate and resistance to vibriosis and viral nervous necrosis in Atlantic cod (Gadus morhua L.). Aquaculture, 317, 67-73.

Briles, W.E., Stone, H.A., \& Cole, R.K. (1977). Marek's disease: effects of B histocompatibility alloalleles in resistant and susceptible chicken lines. Science, 195, 193-5.

Bureau, D.P., Kaushik, S.J., \& Cho, C.Y. (2002). Bioenergetics. In Halver, J.E., \& Hardy, R.W. (Eds.). Fish Nutrition. Elsevier Science. USA, p. 1-59.

Christensen, J.P., Cardin, R.D., Branum, K.C., \& Doherty, P.C. (1999). CD4p T cell-mediated con- trol of a gamma-herpesvirus in B cell-deficient mice is mediated by IFNgamma. Proc. Natl. Acad. Sci. USA, 96, 5135-40.

Heller, K.N., Gurer, C., \& Mu'nz, C. (2006). Virus-specific CD4p T cells: ready for direct attack. J. Exp. Med., 203, 805-8.

Hill, A.V.S., Allsopp, C.E.M., Kwiatkowski, D., Anstey, N.M., Twumasi, P., \& Rowe, P.A. (1991). Common West African HLA antigens are associated with protection from severe malaria. Nature, 352, 595600.

Kaufman, J., \& Wallny, H.J. (1996). Chicken MHC molecules, disease resistance and the evolutionary origins of birds. Curr. Top. Microbiol. Immunol., 212, 129-41.

Kirpichnikov, V.S., Ilyasov, J.I., Shart, L.A., Vikhman, A.A., Ganchenko, M.V., Ostashevky, A.L., Simonov, V.M., Tikhonov, G.F., \& Tjurin, V.V. (1993). Selection of Krasnodar common carp (Cyprinus carpio L.) for resistance to dropsy: principal, results and prospects. Aquaculture, 111, 7-20.

Klein, J., Sato, A., \& Nikolaidis, N. (2007). MHC, TSP, and origin of species: from immunogenetics to evolutionary genetics. Annu. Rev. Genet., 41, 281304.

Landais, E., Saulquin, X., Scotet, E., Trautmann, L., Peyrat, M.A., \& Yates, J.L. (2004). Direct killing of Epstein-Barr virus (EBV)-infected B cells by CD4 T cells directed against EBV lytic protein BHRF1. Blood, 103, 1408-16.

Overturf, K., Lapatra, S., Towner, R., Campbell, N., \& Narum, S. (2010). Relationships between growth and disease resistant in rainbow trout, Oncorhyncus mykiss (Walbaum). J. Fish Disease, 33(4), 321-329.

Rakus, K.L., Wiegertjes, G.F., Adamek, M., Bekh, V., Stet, R.J.M., \& Irnazarow, I. (2008). Application of PCR-RF-SSCP to study major histocompatibility class II B polymorphism in common carp (Cyprinus carpio L.). Fish \& Shellfish Immunology, 24, 734-744.

Shoemaker, C.A., Klesius, P.H., \& Lim, C. (2001). Immunity and disease resistance in fish. In Lim, C., \& Webster, C.D. (Eds.). Nutrition and Fish Health. The Howard Press. Binghamton. New York, p. 149-162.

Wetten, M., Aasmundstad, T., Kjøglum, S., \& Storset, A. (2007). Genetic analysis of resistance to infectious pancreatic necrosis in Atlantic salmon (Salmo salar L.). Aquaculture, 272, 111-117.

Wiertz, E.J., Devlin, R., Collins, H.L., \& Ressing, M.E. (2007). Herpesvirus interference with major histocompatibility complex class II-restricted T-cell activation. J. Virol., 81, 4389-96. 
